\title{
Surface Water Transport for the F/H Area Seepage Basins Groundwater Program (U)
}

by

K. F. Chen

Westinghouse Savannah River Company

Savannah River Site

Aiken, South Carolina 29808

DOE Contract No. DE-AC09-89SR18035

This paper was prepared in connection with work done under the above contract number with the U.S.

Department of Energy. By acceptance of this paper, the publisher and/or recipient acknowledges the U.S. Government's right to retain a nonexclusive, royalty-free license in and to any copyright covering this paper, along with the right to reproduce and to authorize others to reproduce all or part of the copyrighted paper. 


\section{SURFACE WATER TRANSPORT FOR THE F/H AREA SEEPAGE BASINS GROUNDWATER PROGRAM (U)}

Kuo-Fu Chen

Technical Review

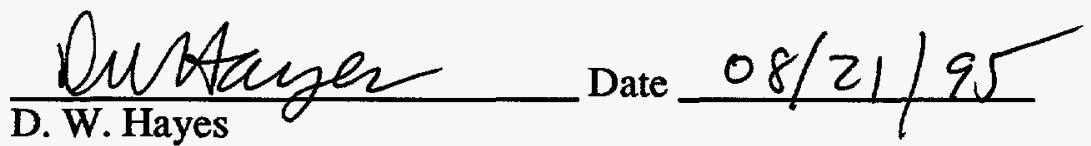

Approvals
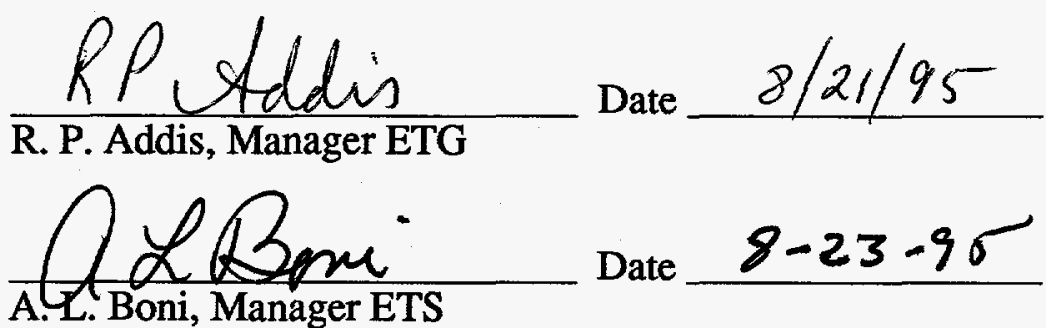

August 1995

Westinghouse Savannah River Company Savannah River Site

Aiken, SC 29808

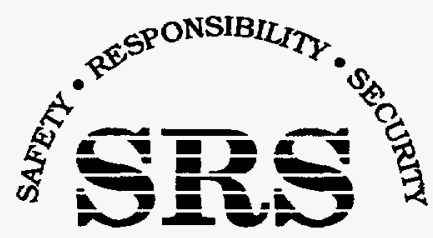

SAVANNAH RIVER SITE

PREPARED FOR THE U.S. DEPARTMENT OF ENERGY UNDER CONTRACT NO. DE-AC09-89SR18035 


\section{DISCLAIMER}

This report was prepared as an account of work sponsored by an agency of the United States Government. Neither the United States Government nor any agency thereof, nor any of their employees, make any warranty, express or implied, or assumes any legal liability or responsibility for the accuracy, completeness, or usefulness of any information, apparatus, product, or process disclosed, or represents that its use would not infringe privately owned rights. Reference herein to any specific commercial product, process, or service by trade name, trademark, manufacturer, or otherwise does not necessarily constitute or imply its endorsement, recommendation, or favoring by the United States Government or any agency thereof. The views and opinions of authors expressed herein do not necessarily state or reflect those of the United States Government or any agency thereof. 


\section{DISCLAIMER}

Portions of this document may be illegible in electronic image products. Images are produced from the best available original document. 
Retention: Lifetime

\title{
SURFACE WATER TRANSPORT FOR THE F/H AREA SEEPAGE BASINS GROUNDWATER PROGRAM (U)
}

\author{
Kuo-Fu Chen
}

Issued: August 1995

SRTC

SAVANNAH RIVER TECHNOLOGY CENTER

AIKEN, SC 29808

Westinghouse Savannah River Company

Savannah River Site Aiken, SC 29808

PREPARED FOR THE U.S. DEPARTMENT OF ENERGY UNDER CONTRACT NO. DE-AC09-89SR18035 


\section{ABSTRACT}

The contribution of the F- and H- Area Seepage Basins (FHSBs) tritium releases to the tritium concentration in the Savannah River are presented in this report. WASP5 was used to simulate surface water transport for tritium releases from the FHSBs. The WASP5 model was qualified with the 1993 tritium measurements at U.S. Highway 301. The tritium concentrations in Fourmile Branch and the Savannah River were calculated for tritium releases from FHSBs. The calculated tritium concentrations above normal environmental background in the Savannah River, resulting from FHSBs releases, drop from $1.25 \mathrm{pCi} / \mathrm{ml}$ (< $10 \%$ of EPA Drinking Water Guide) in 1995 to $0.0056 \mathrm{pCi} / \mathrm{ml}$ in 2045. 


\section{TABLE OF CONTENTS}

1. INTRODUCTION

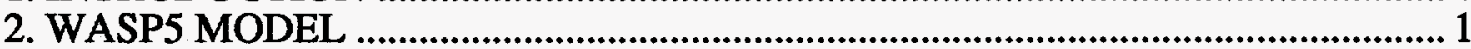

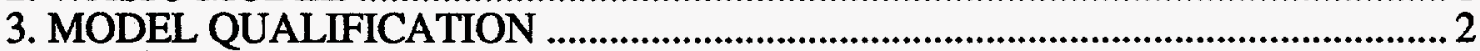

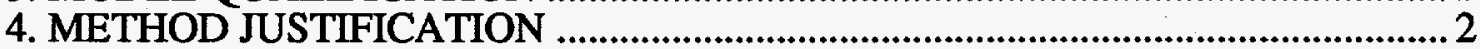

5. CALCULATIONS

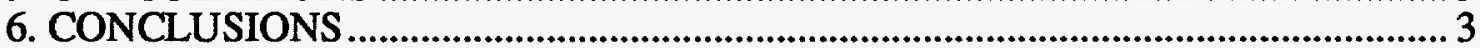

REFERENCES 
Table 1 Estimated Tritium Release in SRS Streams and the Savannah River. 5

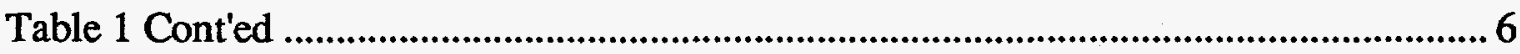

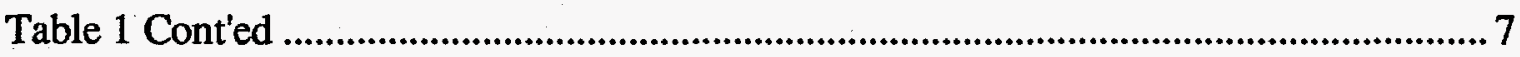

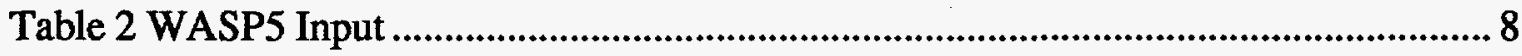

Table 3 WASP5 Calculations for Tritium Concentrations Resulting from FHSBs Releases above Background 9 


\section{LIST OF FIGURES}

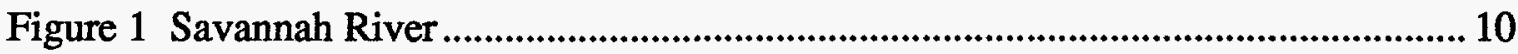

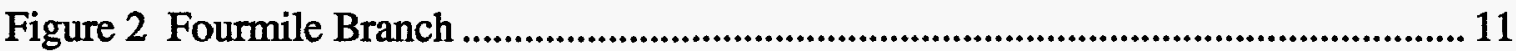

Figure 3 WASP5 Simulations for an Instant Release at FHSBs........................................... 12

Figure 4 Tritium Release Rates from F and H Area Seepage Basins ................................ 13

Figure 5 Source Term from F-Area Seepage Basin for 1996 ............................................... 14

Figure 6 Source Term from H-Area Seepage Basin for 1996........................................... 15

Figure 7 Calculated Tritium Concentration in the Savannah River at Port Wentworth

Figure 8 WASP5 Calculations for Tritium Concentration in the Fourmile Branch

Figure 9 WASP5 Calculations for Tritium Concentration in Savannah River at Downstream of Confluence with Fourmile Branch (Resulting from FHSBs Releases above Background)

Figure 10 WASP5 Calculations for Tritium Concentration in Savannah River at Beauford/Jaspar \& Port Wentworth (Resulting from FHSBs

Releases above Background) 


\title{
SURFACE WATER TRANSPORT FOR THE F/H AREA SEEPAGE BASINS GROUNDWATER PROGRAM (U)
}

\author{
By Kuo-Fu Chen
}

\author{
Westinghouse Savannah River Company \\ Savannah River Site \\ Aiken, SC 29808
}

\section{INTRODUCTION}

The Environmental Transport Group has analyzed the surface water transport of tritium released into Fourmile Branch and the Savannah River from the F- and H-Area seepage basins (FHSBs). This work was performed to support a risk assessment for contamination of drinking water with tritium from FHSBs, which was requested by the SRS Citizens Advisory Board, DOE, EPA and SCDHEC [1].

Reference 1 specified that in-stream concentrations should be calculated for time zero (1995), time zero plus 30 years, and time zero plus 100 years, with the tritium flux (Ci/yr) for the out-years to be obtained from flux modeling previously performed by SRTC [2]. Reference 1 also stipulated that in-stream tritium concentrations should be calculated for Fourmile Branch immediately below the F-Area Seepage Basin discharge zone, in the Savannah River immediately below its confluence with Fourmile Branch, and in the Savannah River at the approximate location of the Beaufort/Jaspar and Port Wentworth water system intakes (using a single point to approximate the location of both intakes). Finally, Reference 1 specified that the transport be modeled using 7Q10 stream flow rates consistent with those used in National Pollution Discharge Elimination System (NPDES) [3] permitting at SRS. It was recommended that the EPA surface water transport model, WASP5 [4], be used to perform the calculations.

\section{WASP5 MODEL}

\section{River Geometry}

WASP5 was used to model both the Savannah River and Fourmile Branch systems. The WASP5 was developed by the EPA to model stream/river systems and to provide predictions of pollutant concentrations and water qualities in surface water systems.

The Savannah River shown in Figure 1 was modeled from River Mile 168 (about 16.46 river miles upstream from the confluence with Fourmile Branch) to River Mile 16 (about 13 river miles downstream from Port Wentworth). To provide adequate detail for prediction of transient releases, the river was divided into 489 segments with a segment length of $500 \mathrm{~m}(0.31 \mathrm{mile})$. An average cross-section of $139 \mathrm{~m}^{2}\left(1500 \mathrm{ft}^{2}\right)$ was used for the river model.

Fourmile Branch shown in Figure 2 was modeled for a distance of $30.5 \mathrm{~km}$ (18.95 miles) which started above the $\mathrm{F}$ and $\mathrm{H}$ seepage basin discharge zones and extended to the Savannah River. Fourmile Branch was divided into 61 segments with a segment length of $500 \mathrm{~m}(0.31$ mile $)$ and an average cross section of $2.97 \mathrm{~m}^{2}\left(31.97 \mathrm{ft}^{2}\right)$ was used. 


\section{MODEL QUALIFICATION}

The WASP5 was qualified by comparing predicted tritium concentrations to measured tritium concentrations at U.S. Highway 301 , about 20 miles downriver of the SRS. Tritium concentration measurements were obtained from Reference 5 as described in the following section.

\section{Tritium Concentration Data}

The average measured tirtium concentration at U.S. Highway 301 bridge for 1993 is $1.24 \pm 0.46 \mathrm{pCi} / \mathrm{ml}$ [Table 24 of Reference 5]. The measured tritium concentrations at U.S. Highway 301 include contributions from all upstream tritium releases. This section presents the method to estimate the tritium concentration that would be measured at U.S. Highway 301 if only the tritium released from the FHSBs was considered.

Sources of tritium releases in SRS streams and the Savannah River are documented in Reference 5 and presented in Table 1 . Table 1 shows that the tritium released from the F-Area Seepage Basin for 1993 accounted for 2,180 Ci and released from H-Area Seepage Basin accounted for 1,020 Ci. The total tritium released to Savannah River including direct releases and migration for 1993 was $12,700 \mathrm{Ci}$. Thus, FHSBs contributed about $25 \%$ of the total tritium released to Savannah River and detected at U.S. Highway 301. The adjusted tritium concentration is $0.31 \pm 0.115 \mathrm{pCi} / \mathrm{ml}$, which would be measured at U.S. Highway 301 if only the tritium released from the FHSBs was counted.

WASP5 Simulations for 1993 Tritium Measurements

WASP5 was used to simulate the surface water transport of tritium released from FHSBs and to calculate the tritium concentration at U.S. Highway 301. The input data required by WASP5 include tritium release rates (Ci/day) from FHSBs, and the flow rates $\left(\mathrm{m}^{3} / \mathrm{s}\right)$ of Fourmile Branch and the Savannah River. The FHSBs releases rates (Ci/yr) for 1993 listed in Table 1 were converted to Ci/day. The annual averaged Savannah River flow rate of $12,218.67 \mathrm{ft}^{3} / \mathrm{s}\left(345.99 \mathrm{~m}^{3} / \mathrm{s}\right)$ and the annual averaged Fourmile Branch flow of $24.51 \mathrm{ft}^{3} / \mathrm{s}\left(0.69 \mathrm{~m}^{3} / \mathrm{s}\right)$ were obtained from References 6 and 7 . The calculated tritium concentration at Highway 301 is $0.293 \mathrm{pCi} / \mathrm{ml}$. The measured tritium concentration contributed by the FHSBs is $0.31 \pm 0.115 \mathrm{pCi} / \mathrm{ml}$. Thus, the calculated tritium concentration at Highway 301 is within the measurement variation.

\section{METHOD JUSTIFICATION}

WASP5 uses a finite difference scheme to solve the one-dimensional transport differential equation. This scheme is subject to the Courant stability limit, which gives a maximum time step of 0.0064 day. With this time step, the SRS VAX computer would take 16 hours to perform a one-year transient simulation. Reference 1 requests for a 100year transient simulation, which would require 2.3 months of computing time. One could increase the segment size from $500 \mathrm{~m}$ to $3,000 \mathrm{~m}$ to reduce the computing time to 12 days. However, this would sacrifice accuracy. An alternate method was used to reduce the computing time without compromising accuracy, as explained in this section.

At 7Q10 flow conditions, it would take about 10.5 days for the tritium released at FHSBs to pass Port Wentworth, as shown in Figure 3. This means that the tritium released at time zero has no effect on the downstream concentration until 10.5 days later. To 
illustrate this point, two test cases were run to find the downstream tritium concentrations at the end of 1996. Case 1 simulated the transient from the beginning of 1996 to the end of 1996 and Case 2 simulated the transient from the 340th day of 1996 to the end of 1996.

Figure 4 presents the tritium release rates from FHSBs [2] for these test cases. The tritium release rates for 1996 are 2106 and $1434 \mathrm{Ci} / \mathrm{yr}$ from the $\mathrm{F}$ and $\mathrm{H}$ Area Seepage Basins, respectively. A linear decrease model was assumed to convert the release rate from curie per year to curie per day, as shown in Figures 5 and 6. Figure 7 depicts the calculated tritium concentration in the Savannah River at Port Wentworth. The results in this figure show that the calculated concentration at the end of year is not affected by the starting time for the transient. Consequently, there is no need to run a transient from the beginning of the year to find the concentration at the end of the year. Figure 7 also shows that the calculated tritium concentration first increases and then decreases as the tritium front passes. The decrease in concentration is due to the decrease in the source term. The transient time required for the tritium concentration to peak at Port Wentworth is about 11 days. Thus, one can save computing time by conducting short transient simulations (> 11 days) to obtain the peak concentrations for instantaneous releases from FHSBs.

Results from these instantaneous release calculations can be combined to obtain an approximate long-term concentration profile for continuous releases.

\section{CAlCulations}

Using the method outlined in the previous section, nine transient calculations were performed, for the years 1995, 2005, 2015, 2025, 2035, 2045, 2055, 2065 and 2088, as shown in Table 2. No calculations were performed for later dates, because the tritium source concentration drops to about zero beyond 2088. Table 2 lists the input conditions. Table 3 and Figures 8 through 10 illustrate the results.

As shown in these figures, the tritium concentrations decrease with time because, after the FHSBs were closed in 1988, seepage of water began to flush the tritium contaminants from the system. The calculated tritium concentration in the Savannah River drops from about $1.25 \mathrm{pCi} / \mathrm{ml}$ in 1995 and to less than $0.0056 \mathrm{pCi} / \mathrm{ml}$ after 2045 . The calculated tritium concentration in Fourmile Branch is about 500 times higher than that in the Savannah River because the Fourmile Branch flow rate $\left(7.2 \mathrm{ft}^{3} / \mathrm{s}\right)$ is much lower than that of the Savannah River $\left(3600 \mathrm{ft}^{3} / \mathrm{s}\right)$, so that the tritium flux is diluted significantly as it mixed with the Savannah River flow.

\section{CONCLUSIONS}

The contribution of the FHSBs tritium releases to the tritium concentration in the Savannah River were studied. WASP5 was used to simulate surface water transport for tritium releases from the FHSBs. The WASP5 model was qualified with the 1993 tritium measurements at U.S. Highway 301. The tritium concentrations in Fourmile Branch and the Savannah River were calculated for tritium releases from FHSBs. The calculated tritium concentrations above normal environmental background in the Savannah River, resulting from FHSBs releases, drop from $1.25 \mathrm{pCi} / \mathrm{ml}(<10 \%$ of EPA Drinking Water Guide) in 1995 to $0.0056 \mathrm{pCi} / \mathrm{ml}$ in 2045 . 


\section{REFERENCES}

1.David W. Nix, "Technical Assistance Request: Surface Water Transport Modeling for F/H Seepage Basin Groundwater Risk Assessment," May 15, 1995.

2. Looney, B. B., "Background Information on Tritium Releases from F\&H Area Seepage Basin Groundwater Plumes: Meeting Notes and Draft Text," SRT-ESS-94-245, February 21, 1994.

3. "NPDES Draft Permit \#SC0000175 Renewal," March, 1995.

4. Ambrose, Robert B., Wool, Tim A. and Martin, James L., "The Water Quality Analysis Simulation Program, WASP5, Part A: Model Documentation; Part B: Input Dataset," Environmental Research Laboratory, Office of Research and Development, U.S. Environmental Protection Agency, Athens, Georgia, September 20, 1993.

5. Arnett, Margaret W., "Savannah River Site Environmental Data for 1993," WSRC-TR94-077.

6. "Water Resources Data South Carolina Water Year 1993," U.S. Geological Survey Water-Data Report SC-93-1.

7. "Water Resources Data South Carolina Water Year 1994," U.S. Geological Survey Water-Data Report SC-94-1. 
Table 1 Estimated Tritium Release in SRS Streams and the Savannah River

Page 1 of 3

\begin{tabular}{|c|c|c|c|c|c|c|c|}
\hline \multicolumn{8}{|c|}{ Dlrect Roleases (Curies) } \\
\hline Area & Relesse Polnt & 1988 & 1989 & 1890 & 1991 & 1992 & 1893 \\
\hline \multicolumn{2}{|l|}{ Reactor } & & & & $=$ & & \\
\hline \multirow[t]{4}{*}{$100-p$} & $\begin{array}{l}\text { Par Pond overflow to Lower- } \\
\text { Three Runs Creek }\end{array}$ & 327 & $(321)^{2}$ & $(207)^{a}$ & 221 & 100 & 64 \\
\hline & - Process sewer to Par Pond & & 164 & 67 & $(43)^{a}$ & & \\
\hline & $\begin{array}{l}\text { "Reactor heat axchanger cool- } \\
\text { ing water to Par Pond }\end{array}$ & & 464 & 125 & $(67)^{\mathrm{a}}$ & & \\
\hline & Combined in 1992 (P019) & & & & & $(8)^{\mathrm{a}}$ & $(3)^{\mathrm{a}}$ \\
\hline \multirow[t]{4}{*}{$100-L$} & $\begin{array}{l}\text { L-Lake overtlow to Steed } \\
\text { Creek }\end{array}$ & 502 & $(556)^{a}$ & $(358)^{\mathrm{a}}$ & 723 & 515 & 650 \\
\hline & - Process sewer to L Lake & & 24 & 27 & $(11)^{a}$ & & \\
\hline & $\begin{array}{l}\text { "Reector hea: exchanger cool- } \\
\text { ingwater to L Lake }\end{array}$ & & 98 & 72 & $(112)^{a}$ & & \\
\hline & "Combined in 1992 (L007) & & & & & $(58)^{2}$ & $(9)^{4}$ \\
\hline \multirow[t]{5}{*}{$100-K$} & - Process sewer to Pen Branch & 264 & 100 & 169 & 74 & & \\
\hline & $\begin{array}{l}\text { - Reactor heat exchanger cool- } \\
\text { ingwater to Pen Branch }\end{array}$ & 2,470 & 112 & 249 & $6,470^{\circ}$ & & \\
\hline & $\begin{array}{l}\text { Combined in } 1992 \\
\text { (K-Canal) }\end{array}$ & & & & & 125 & 16 \\
\hline & $(K \infty \infty 8)$ & & & & & 3 & \\
\hline & K-Area secondary effluent & & & & 6 & 3 & \\
\hline \multirow[t]{2}{*}{$100-C$} & $\begin{array}{l}\text { Process Sewer to Four Mile } \\
\text { Greek (C-Canal) }\end{array}$ & 11 & 16 & 1 & 13 & 28 & 12 \\
\hline & Subtotal & 3,570 & 978 & 710 & 7,510 & 775 & 742 \\
\hline \multicolumn{8}{|c|}{ Separations } \\
\hline \multirow[t]{2}{*}{$200-F$} & Etiluent to Four Mile Creek & 14 & 8 & 327 & 6 & 5 & 4 \\
\hline & Effluent to Upper Three Runs & & 2 & 0 & 0 & 1 & 1 \\
\hline \multirow[t]{4}{*}{$200-H$} & Effluent to Four Mile Creek & 12 & 20 & 22 & 14 & 13 & 12 \\
\hline & Effluent to Upper Throe Runs & & 1 & 4 & 5 & 15 & 17 \\
\hline & Effluent Treatment Facility & 101 & 2.070 & 1,200 & 3,070 & $1.0: 0$ & 395 \\
\hline & Subtotal & 127 & 3,100 & 1,550 & 3,090 & 1,040 & 425 \\
\hline \multirow[t]{3}{*}{$400-0$} & $\begin{array}{l}\text { Process sewe: 10 Beaver Dam } \\
\text { Creek }\end{array}$ & 1.740 & 562 & 358 & 681 & 576 & 499 \\
\hline & Subtotal & 1,740 & 562 & 358 & 681 & 576 & 499 \\
\hline & Total Direct Releases ${ }^{\circ}$ & 5,440 & 3,640 & 2,620 & 11,300 & 2,390 & 1,670 \\
\hline $\begin{array}{ll}a & \text { Not } \\
b & \text { Inclu } \\
c & \text { Boct }\end{array}$ & $\begin{array}{l}\text { used in totals because release was co } \\
\text { des heat exchanger leak of Decembe } \\
\text { ause of roundling, sums of Individual o }\end{array}$ & $\begin{array}{l}\text { tod elsew } \\
2-25,199 \\
\text { mns migh }\end{array}$ & Bqual totals. & & & & \\
\hline
\end{tabular}


Table 1 Cont'ed

Page 2 of 3

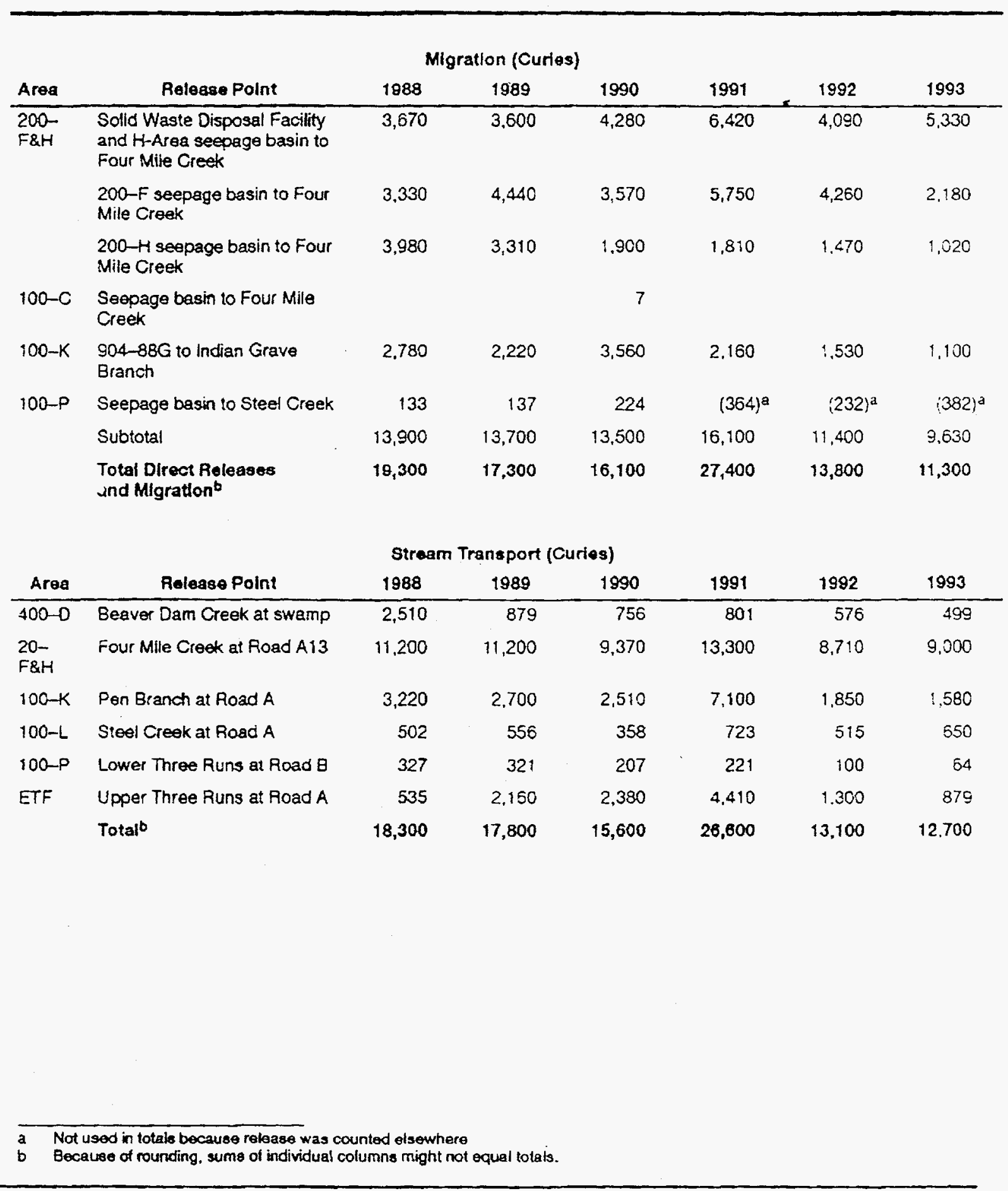


Table 1 Cont'ed

Page 3 of 3

\begin{tabular}{|c|c|c|c|c|c|c|}
\hline \multicolumn{7}{|c|}{ River Transport (Curies) } \\
\hline & 1988 & 1989 & 1990 & $1991^{\circ}$ & 1992 & 1993 \\
\hline $\begin{array}{l}\text { Tritlum measured in the Savannah River } \\
\text { below SRS }\end{array}$ & & 17.110 & 16,570 & 28,700 & 16,000 & 12,600 \\
\hline $\begin{array}{l}\text { Tritium measured in the Savannah Rivet } \\
\text { above SRS }\end{array}$ & & 1.480 & 2,080 & 2,420 & 2,210 & 433 \\
\hline $\begin{array}{l}\text { Tritlum measured in the Savannah } \\
\text { River below SRS (downriver minus } \\
\text { upriver)" }\end{array}$ & 14,600 & 15,600 & 14,490 & 26,300 & 13,800 & 12,200 \\
\hline
\end{tabular}


Table 2 WASP5 Input

Fourmile Branch 7Q10 Flow

$\begin{array}{cc}\text { Year } & \mathrm{ft}^{3} / \mathrm{s}\left(\mathrm{m}^{3} / \mathrm{s}\right) \\ 1995 & 7.2(0.20388) \\ 2005 & 7.2(0.20388) \\ 2015 & 7.2(0.20388) \\ 2025 & 7.2(0.20388) \\ 2035 & 7.2(0.20388) \\ 2045 & 7.2(0.20388) \\ 2055 & 7.2(0.20388) \\ 2065 & 7.2(0.20388) \\ 2088 & 7.2(0.20388)\end{array}$

Savannah River
7Q10 Flow

$$
\mathrm{ft}^{3} / \mathrm{s}\left(\mathrm{m}^{3} / \mathrm{s}\right)
$$

3600 (101.9406)

3600 (101.9406)

3600 (101.9406)

3600 (101.9406)

3600 (101.9406)

3600 (101.9406)

3600 (101.9406)

3600 (101.9406)

3600 (101.9406)
Seepage Basin Release Rate

F-Area

H-Area

Ci/day

$\mathrm{Ci} /$ day

6.495890

1.772603

0.479452

0.139726

0.043836

0.013699

0.005479

0.002740

0.0
4.547945

1.290411

0.463014

0.186301

0.079452

0.035616

0.016438

0.008219

0.002740 
Table 3 WASP5 Calculations for Tritium Concentrations Resulting from FHSBs Releases above Background

Fourmile Branch at Road A

$\begin{array}{cc}\text { Year } & \mathrm{pCi} / \mathrm{ml} \\ 1995 & 6.268 \mathrm{E}+02 \\ 2005 & 1.738 \mathrm{E}+02 \\ 2015 & 5.349 \mathrm{E}+01 \\ 2025 & 1.850 \mathrm{E}+01 \\ 2035 & 6.997 \mathrm{E}+00 \\ 2045 & 2.799 \mathrm{E}+00 \\ 2055 & 1.244 \mathrm{E}+00 \\ 2065 & 6.219 \mathrm{E}-01 \\ 2088 & 1.555 \mathrm{E}-01\end{array}$

Savannah River downstream from Confluence with Fourmile Branch
Savannah River at Beaufort/Jaspar and Port Wentworth $\mathrm{pCi} / \mathrm{ml}$
$1.250 \mathrm{E}+00$
$3.467 \mathrm{E}-01$
$1.067 \mathrm{E}-01$
3.690E-02
$1.395 \mathrm{E}-02$
$5.580 \mathrm{E}-03$
$2.481 \mathrm{E}-03$
$1.240 \mathrm{E}-03$
3.101E-04 
Figure 1 Savannah River
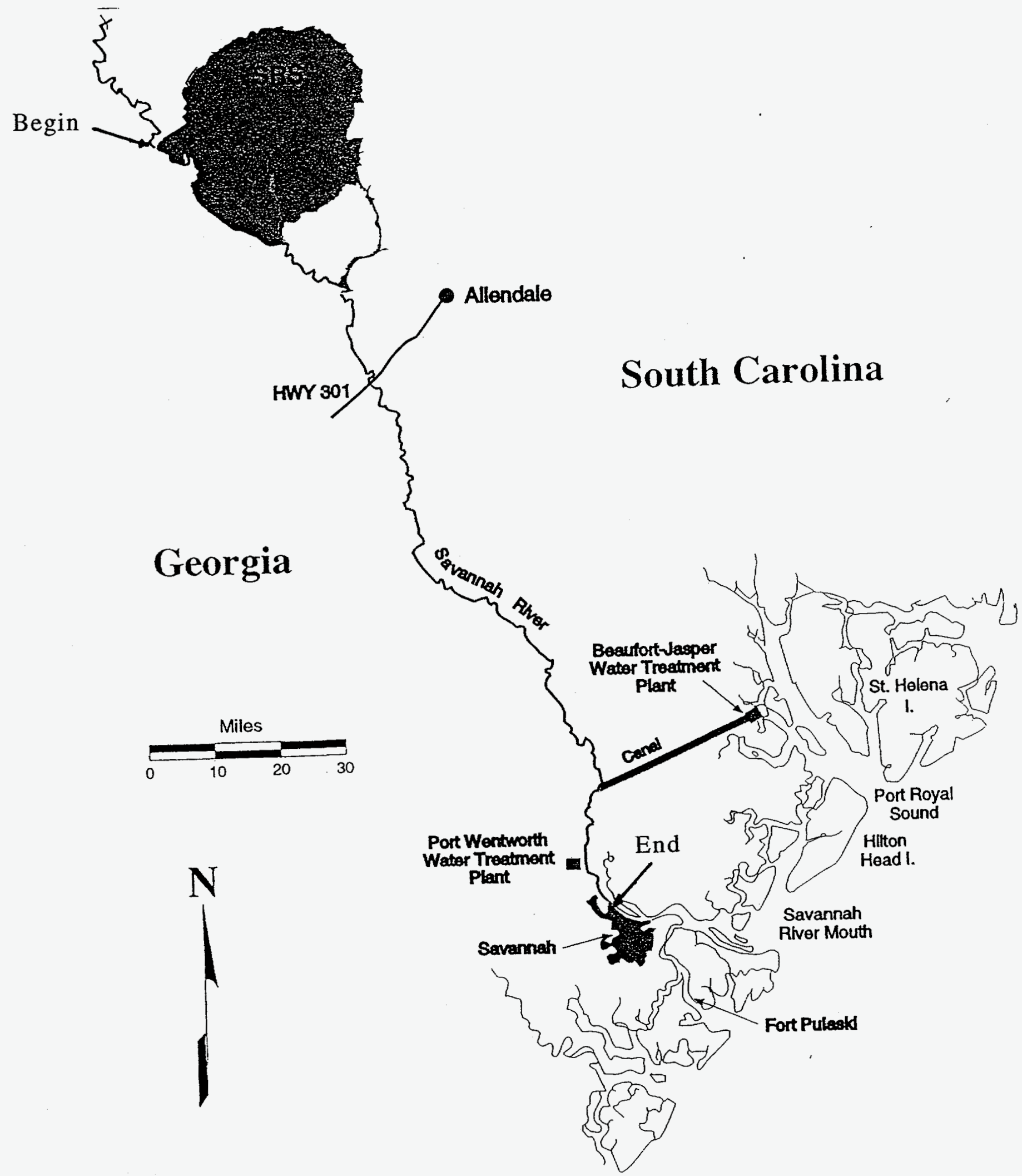

\section{South Carolina}


Figure 2 Fourmile Branch

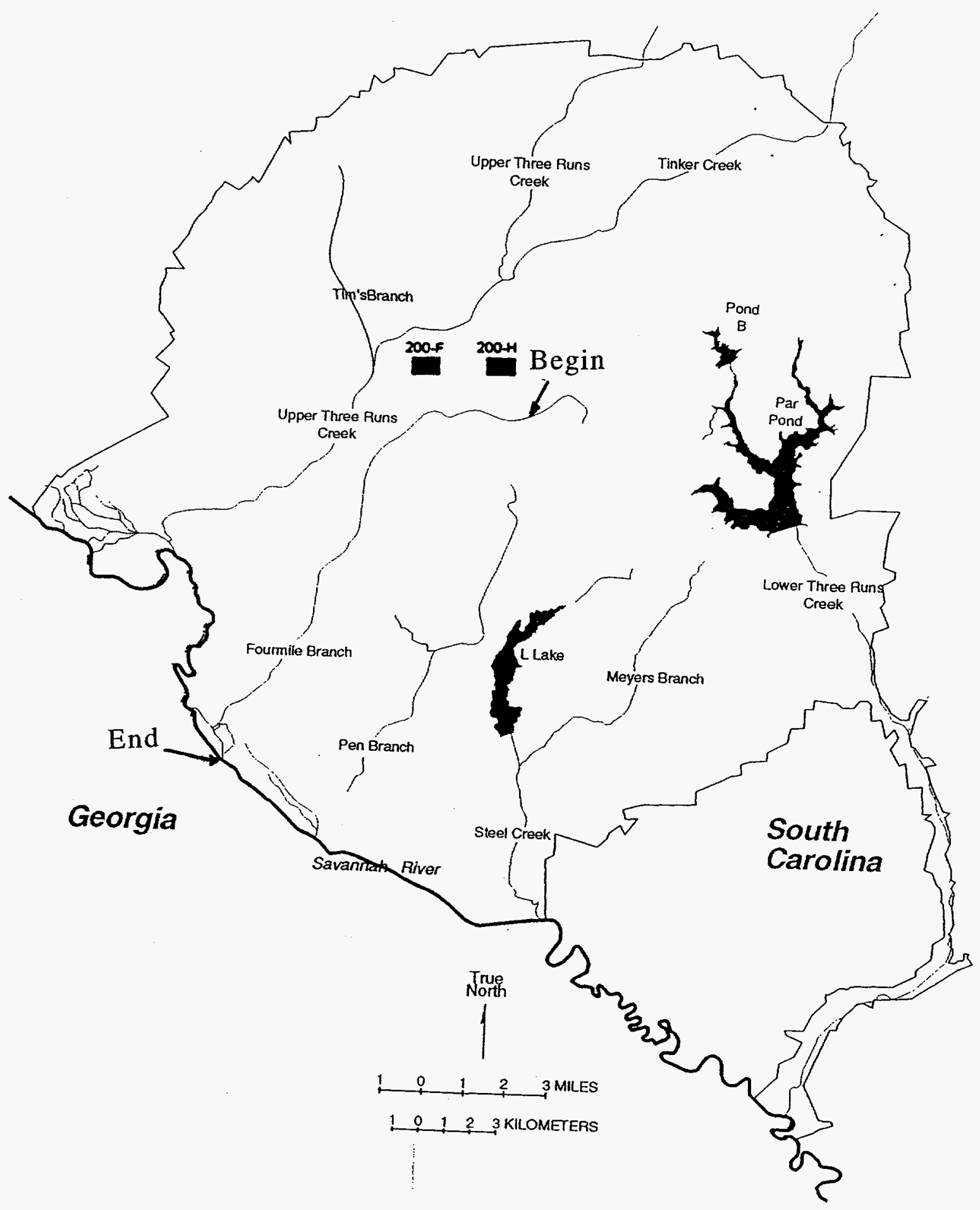


Figure 3 WASP5 Simulations for an Instant Release at FHSBs

(Using 7Q10 Flow Conditions)

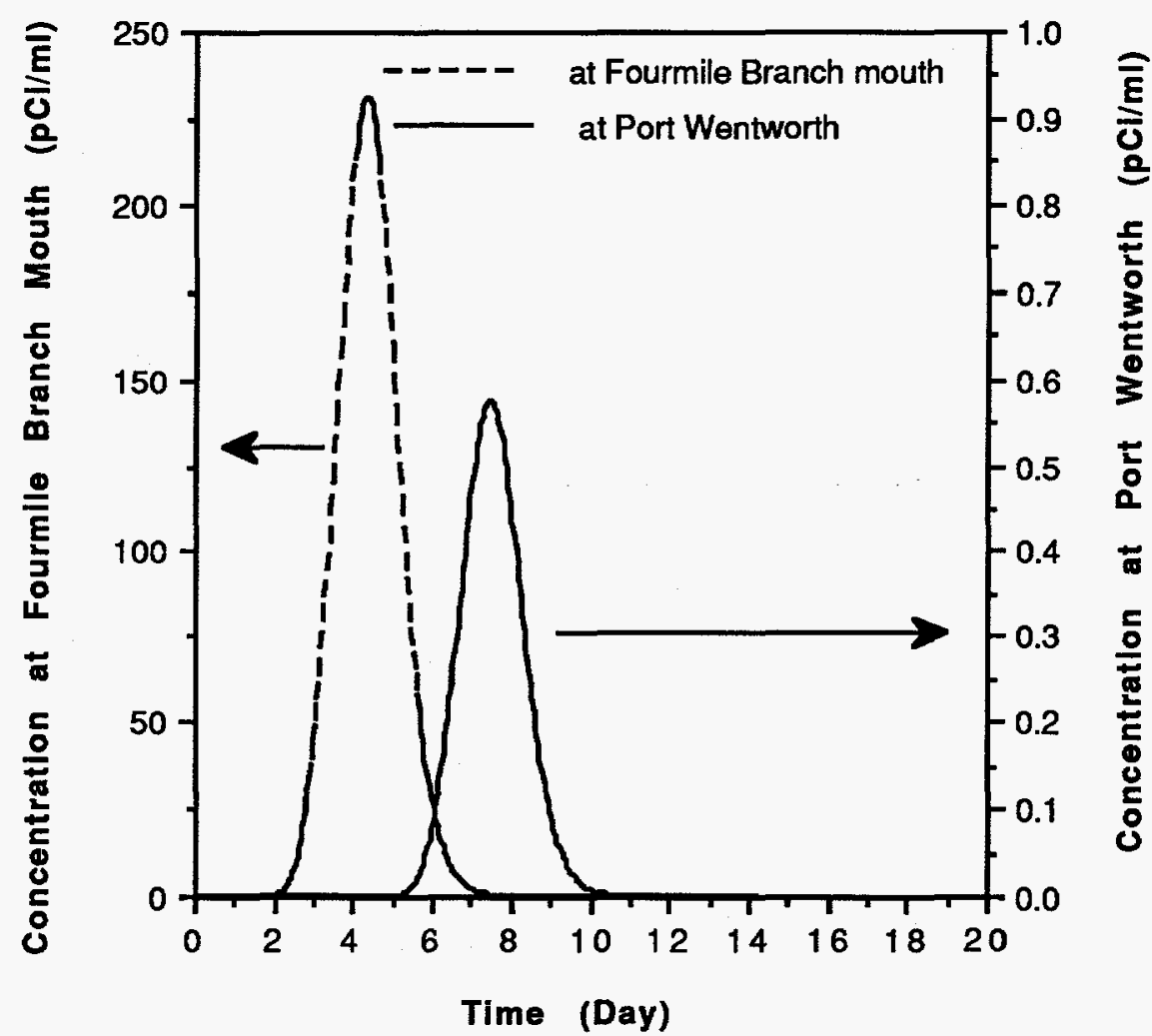


Figure 4 Tritium Release Rates from F and H Area Seepage Basins

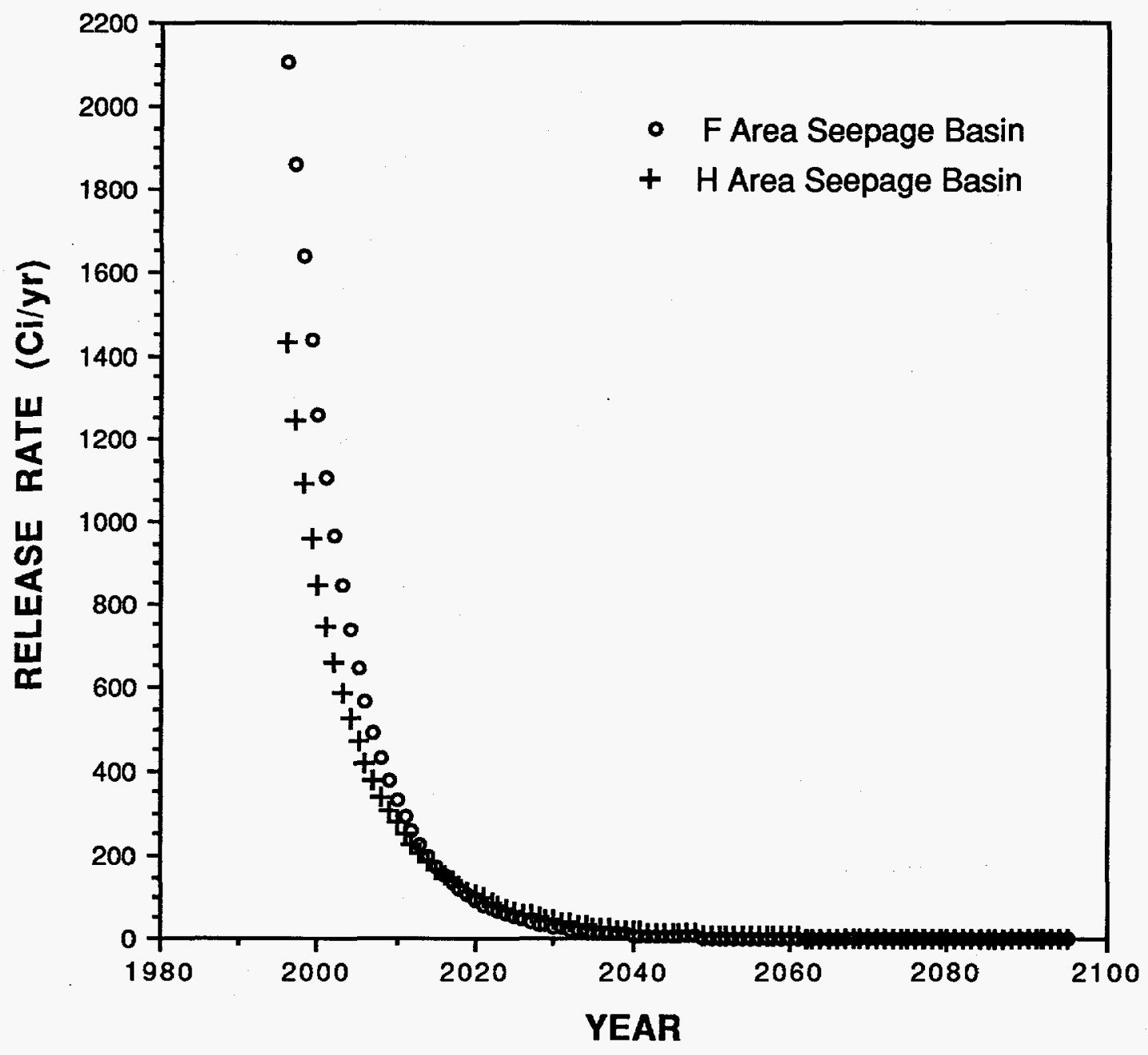


Figure 5 Source Term from F-Area Seepage Basin for 1996

(Linear Approximation was used)

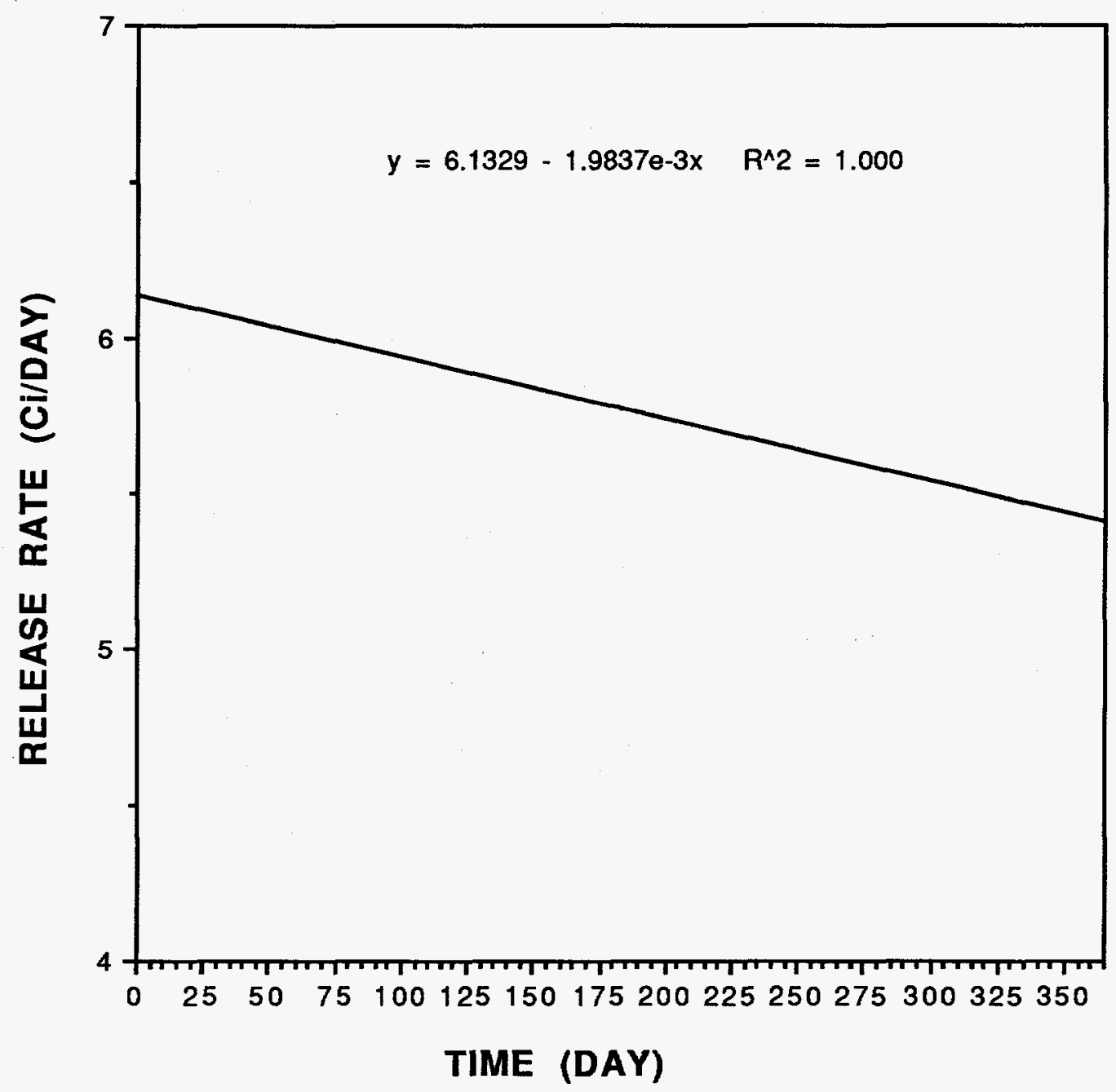


Figure 6 Source Term from H-Area Seepage Basin for 1996

(Linear Approximation was used)

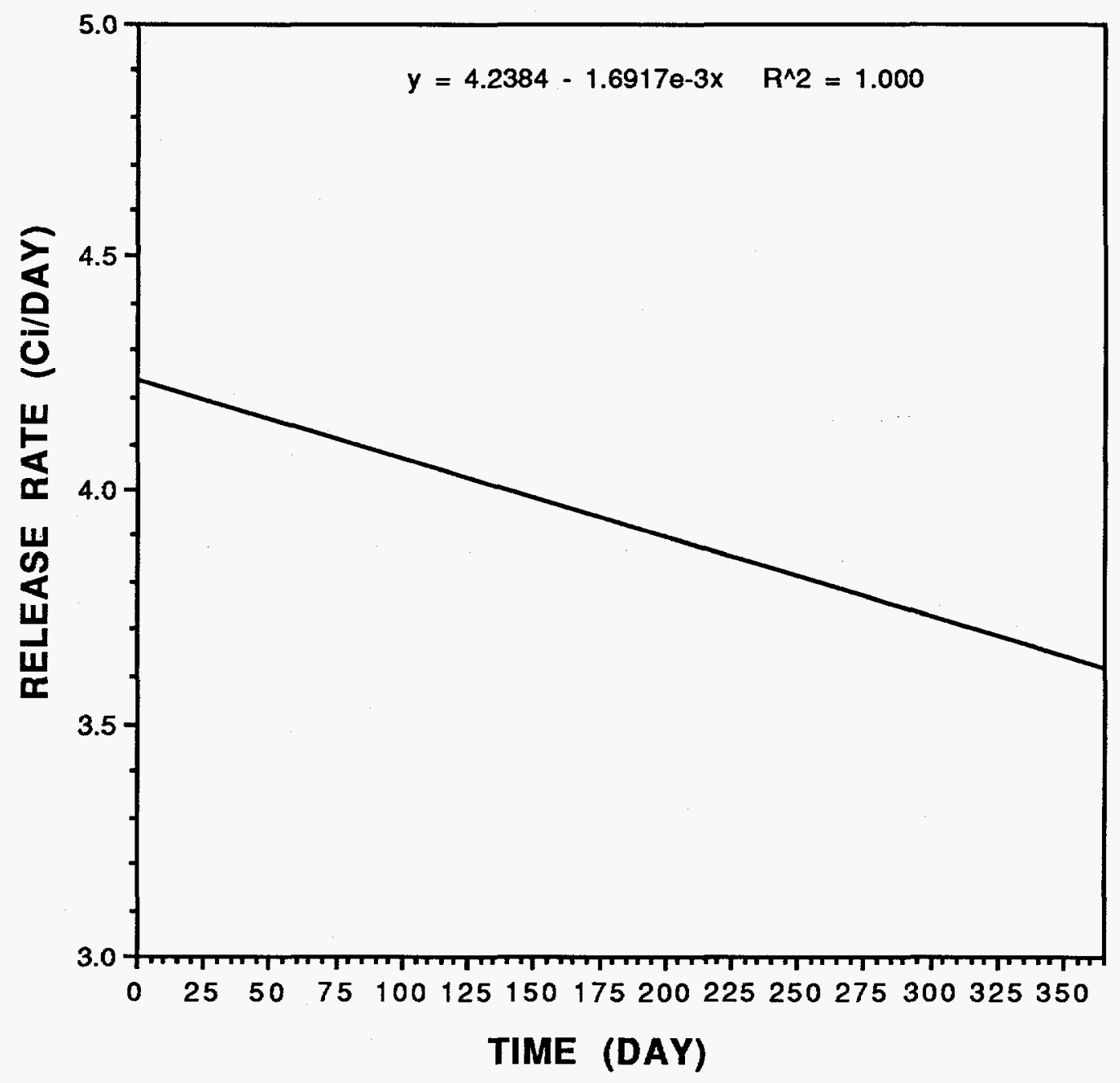


Figure 7 Calculated Tritium Concentration in the Savannah River at Port Wentworth

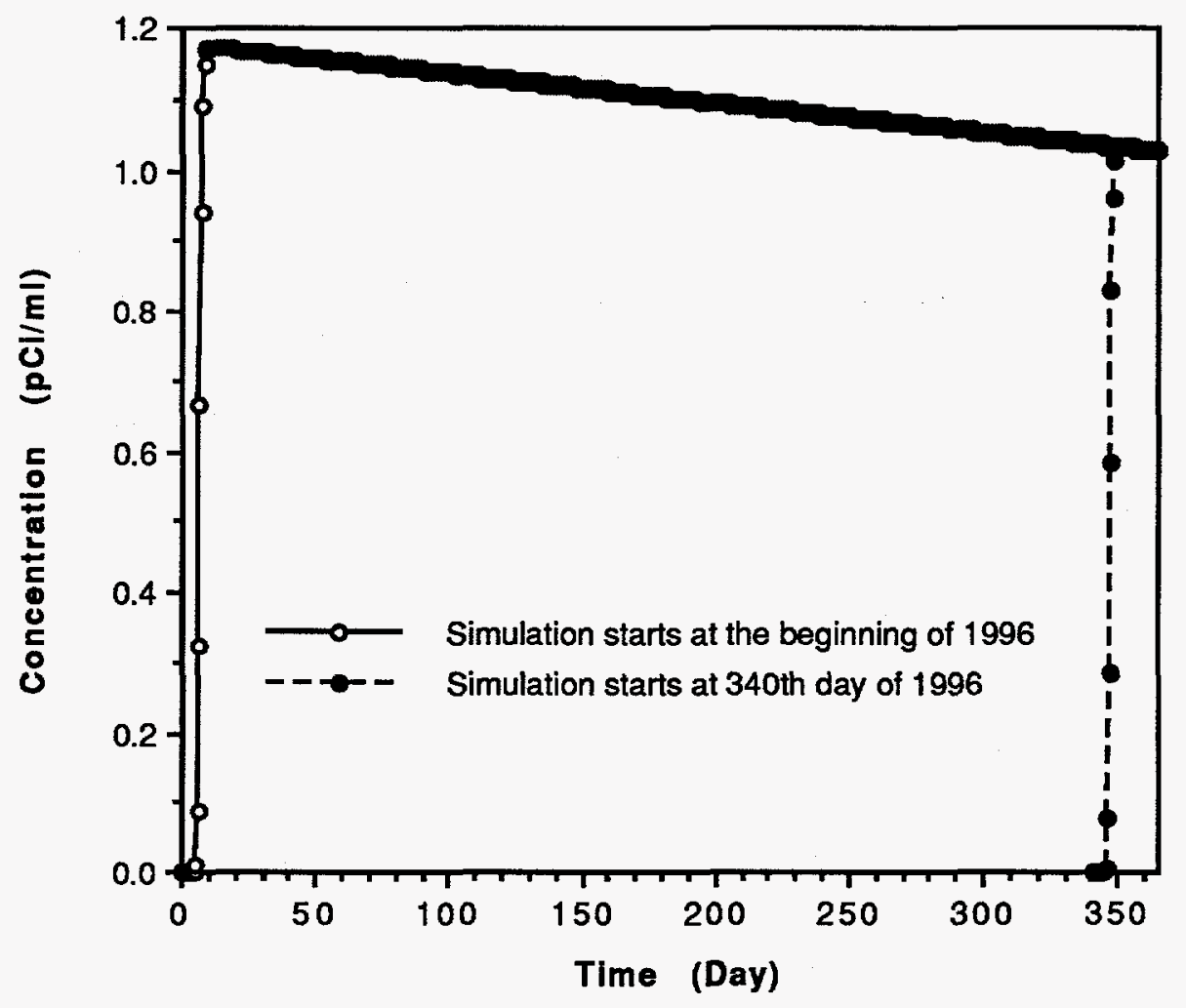


Figure 8 WASP5 Calculations for Tritium Concentration in the Fourmile Branch at Road A (Resulting from FHSBs Releases above Background)

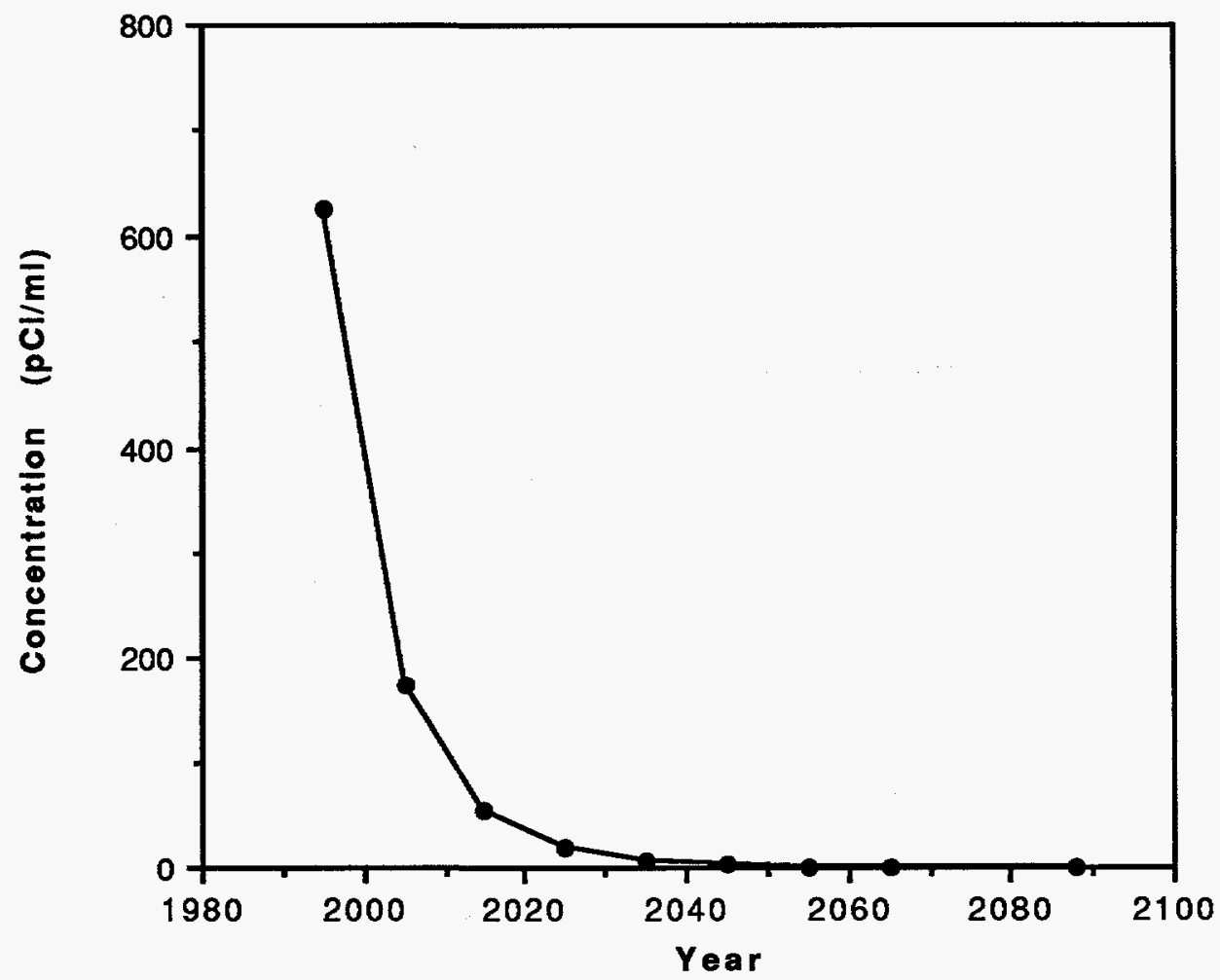


Figure 9 WASP5 Calculations for Tritium Concentration in Savannah River at Downstream of Confluence with Fourmile Branch (Resulting from FHSBs Releases above Background)

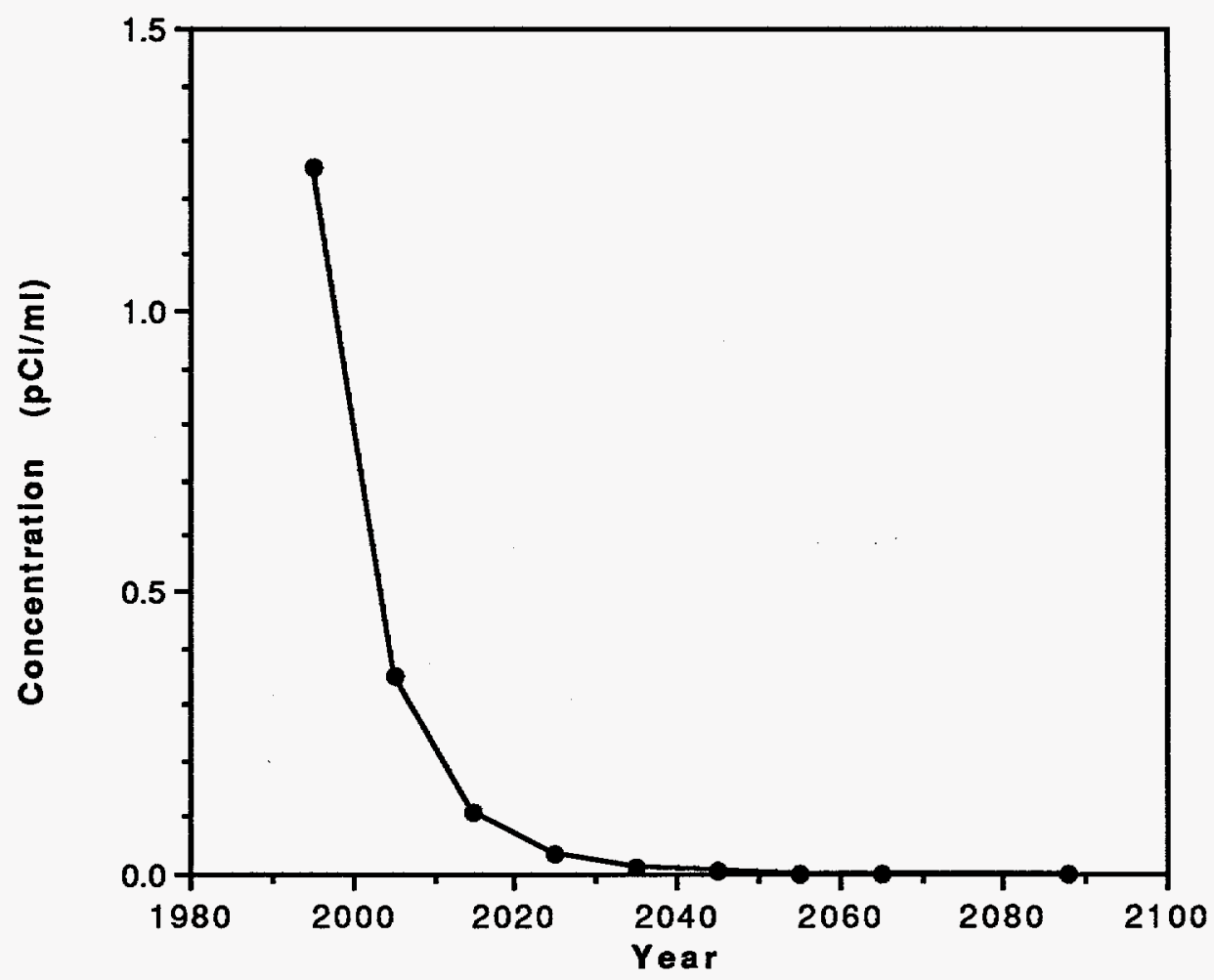


Figure 10 WASP5 Calculations for Tritium Concentration in Savannah River at Beauford/Jaspar \& Port Wentworth (Resulting from FHSBs Releases above Background)

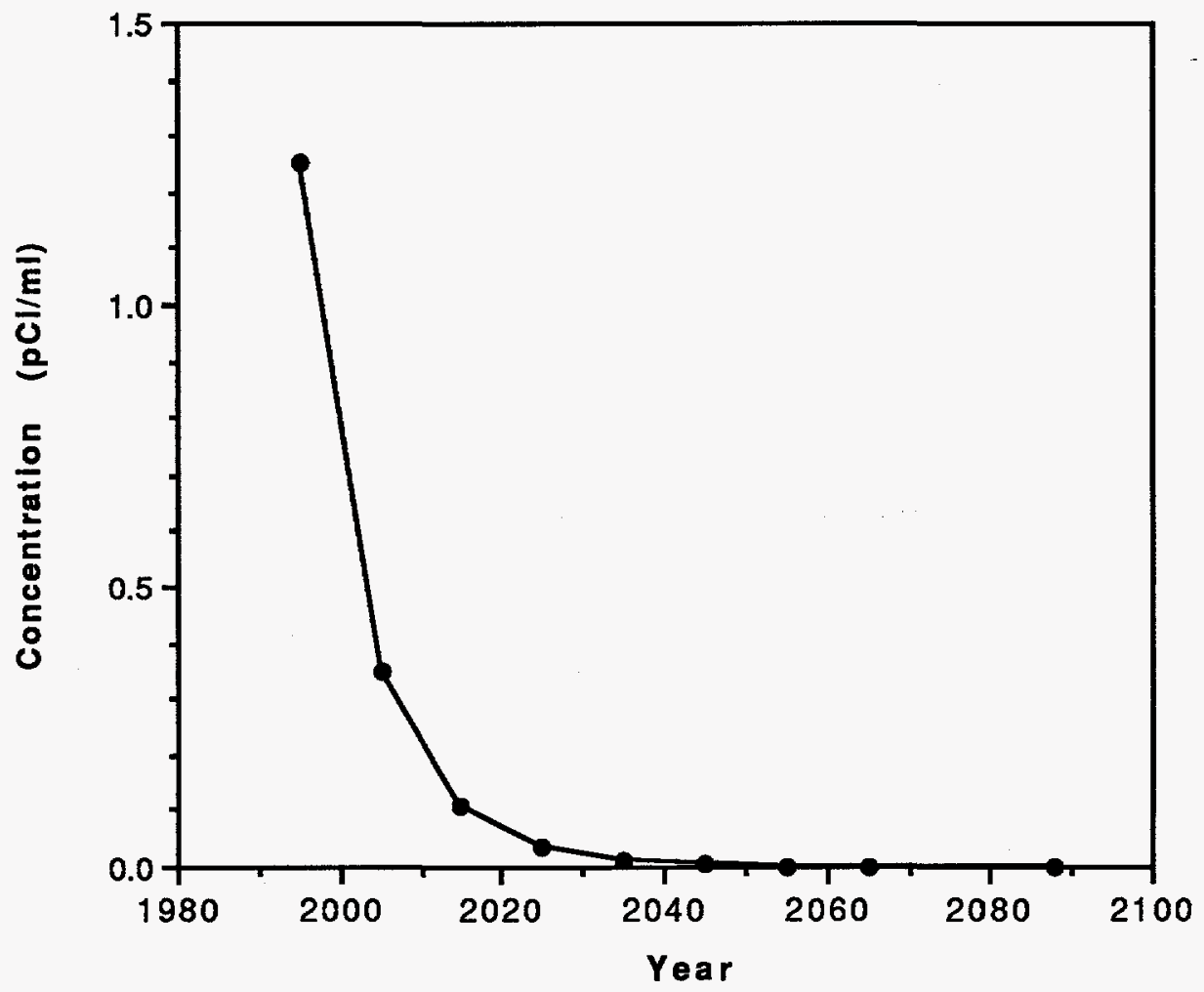


SURFACE WATER TRANSPORT FRO THE F/H AREA SEEPAGE BASINS

GROUNDWATER PROGREM(U)

\section{DISTRIBUTION}

R. P. Addis, 773-A

A. L. Boni, 773-A

David W. Nix, 992-4W

B. A. Hamm, 992-4W

A. J. Garrett, 773-A

D. W. Hayes, 735-A

Kuo-Fu Chen, 773-A

SRTC Records(4), 773-52A

ETG Records(5), 773-A 